\title{
Perspektif Kemudahan Akses Lokasi dengan Kepuasan Pasien UPTD Puskesmas Sekar Jaya Tahun 2020
}

Febrianti Gusparini

UPTD Puskesmas Sekarjaya

Dinas Kesehatan $\mathrm{OKU}$

Informasi Artikel :

Diterima : 04 April 2021

Direvisi : 15 Mei 2021

Disetujui : 29 Mei 2021

Diterbitkan : 15 Juni 2021

*Korespondensi Penulis : febriantigusparini@gmail.com

\section{A B S T R A K}

Kemudahan akses menuju lokasi puskesmas merupakan salah satu kriteria pasien dalam memilih pelayanan kesehatan yang dibutuhkan. Pada masa sekarang ini dimana pembangunan dan perkembangan transportasi, teknologi dan penerapan pelayanan on line sangat memudahkan bagi masyarakat untuk memilih tempat pelayanan kesehatan yang diinginkan. Penelitian ini menilai Perspektif kemudahan akses ke lokasi puskesmas dengan kepuasan pasien yang menerima pelayanan di UPTD Puskesmas Sekar Jaya tahun 2020 dengan desain Penelitian analitik dengan dengan desain cross sectional dan dengan menggunakan dua instrumen penelitian yaitu quesioner kemudahan akses dan quesioner kepuasan pelanggan pada tanggal 1 Nopember sampai dengan 1 Desember 2020 dengan jumlah sampel 80 sampel. Dalam menganalisa hasil penelitian, peneliti menggunakan uji ChiSquare dan didapatkan hasil bahwa kemudahan dalam mencapai lokasi (geografis), Aksesbilitas transportsi umum dan ketersediaan lahan parkir yang memadai memiliku hubungan yang bermakna pada kepuasan pasien.

Kata Kunci: kemudahan akses, kepuasan pasien.

\section{ABTRACT}

Ease of access to the puskesmas location is one of the criteria for patients in choosing the necessary health services. In this day and age where the development and development of transportation, technology and the application of services on line is very easy for the public to choose the desired place of health services. This study assessed the perspective of ease of access to the puskesmas location with the satisfaction of patients who received services at UPTD Puskesmas Sekar Jaya in 2020 with analytical research design with cross sectional design and by using two research instruments namely quesioner ease of access and quesioner customer satisfaction on November 1 to December 1, 2020 with a sample number of 80 samples. In analyzing the results of the study, researchers used the Chi-Square test and obtained the results that the ease in achieving location (geographic), public transportability and the availability of adequate parking spaces have a meaningful relationship to patient satisfaction.

Keywords: ease of access, patient satisfaction. 


\section{PENDAHULUAN}

Dalam mencapai tujuan nasional seperti yang tercantum dalam dalam pembukaan Undang-Undang Dasar 1945 diseleggarakan upaya pembangunan yang berkesinambungan dalam rangkaian program pembangunan yang menyeluruh terarah dan terpadu. Upaya pembangunan ini diharapkan dapat mewujudkan suatu tingkat kehidupan masyarakat secara optimal, termasuk peningkatan kesehatan.

Kesehatan adalah hak dan investasi semua warga negara. Untuk menjamin kesehatan diperlukan suatu sistem yang mengatur penyelenggaraan pelayanan kesehatan bagi masyarakat sebagai upaya pemenuhan kebutuhan warga negara untuk tetap hidup sehat. Pelayanan kesehatan yang memadai merupakan tumpuan masyarakat dan menjadi salah satu kebutuhan mendasar selain pangan dan juga pendidikan (Sinambela, 2015).

Undang-Undang Nomor 36 Tahun 2009 tentang kesehatan, Pelayanan kesehatan yang berkualitas adalah pelayanan kesehatan yang peduli dan terpusat pada kebutuhan, harapan serta nilai-nilai pelanggan sebagai titik tolak penyediaan pelayanan kesehatan dan menjadi persyaratan yang harus dapat dipenuhi agar dapat memberikan kepuasan kepada masyarakat sebagai pengguna jasa pelayanan. Masyarakat berharap untuk mendapatkan penyelenggaraan pelayanan kesehatan dilaksanakan secara bertanggungjawab, aman, berkualitas serta merata dan nondiskriminatif, sehingga hakhak pasien sebagai penerima pelayanan kesehatan tersebut dapat terlindungi.

Salah satu bentuk upaya pemerintah dalam Undang-Undang Nomor 36 Tahun 2009 yaitu menyelenggarakan kesehatan kepada masyarakat maka disetiap kecamatan dibangun instansi pemerintah sebagai unit penyelenggara pelayanan kesehatan masyarakat, yakni Pusat Kesehatan Masyarakat atau yang biasa disebut Puskesmas.
Permenkes 43 tahun 2019 tentang Puskesmas menyebutkan bahwa Puskesmas adalah Fasilitas Pelayanan Kesehatan (FasKes). Fasilitas Pelayanan Kesehatan adalah suatu tempat yang digunakan untuk menyelenggarakan upaya pelayanan kesehatan, baik promotif, preventif, kuratif maupun rehabilitatif yang dilakukan oleh pemerintah, pemerintah daerah dan/atau masyarakat. Upaya Kesehatan Masyarakat yang selanjutnya disingkat UKM adalah setiap kegiatan untuk memelihara dan meningkatkan kesehatan serta mencegah dan menanggulangi timbulnya masalah kesehatan dengan sasaran keluarga, kelompok dan masyarakat.

Peraturan Menteri Kesehatan Republik Indonesia Nomor 75 Tahun 2014 menjelaskan bahwa, pembangunan kesehatan yang diselenggarakan di Puskesmas bertujuan untuk mewujudkan wilayah kerja Puskesmas yang sehat, dengan masyarakat yang. memiliki perilaku sehat yang meliputi kesadaran, kemauan, dan kemampuan hidup sehat,. mampu menjangkau Pelayanan Kesehatan bermutu, hidup dalam lingkungan sehat; dan memiliki derajat kesehatan yang optimal, baik individu, keluarga, kelompok dan masyarakat.

Puskesmas adalah fasilitas pelayanan kesehatan yang menyelenggarakan upaya kesehatan masyarakat dan upaya kesehatan perseorangan tingkat pertama, dengan lebih mengutamakan upaya promotif dan preventif, untuk mencapai derajat kesehatan masyarakat yang setinggi-tingginya di wilayah kerjanya. Puskesmas merupakan organisasi fungsional yang menyelenggarakan upaya kesehatan yang bersifat menyeluruh, terpadu, merata, dapat diterima dan terjangkau masyarakat, dengan peran serta aktif masyarakat dan menggunakan hasil pengembangan ilmu pengetahuan dan teknologi tepat guna, dengan biaya yang dapat dipikul oleh pemerintah dan masyarakat. Upaya kesehatan tersebut diselenggarakan dengan menitikberatkan kepada pelayanan untuk masyarakat luas guna mencapai derajat kesehatan yang optimal, tanpa mengabaikan 
kualitas kepada perorangan. Puskemas merupakan unit pelaksana teknis kesehatan di bawah supervisi Dinas Kesehatan Kabupaten/Kota. Secara umum, mereka harus memberikan pelayanan preventif, promotif, kuratif sampai dengan rehabilitatif baik melalui Upaya Kesehatan Perorangan (UKP) atau Upaya Kesehatan Masyarakat (UKM). Puskesmas dapat memberikan pelayanan rawat inap selain pelayanan rawat jalan.

Upaya kesehatan di Puskesmas terbagi menjadi Upaya Kesehatan Masyarakat dan Upaya Kesehatan Perseorangan meliputi upaya kesehatan masyarakat esensial yang terdiri dari pelayanan promosi kesehatan, kesehatan lingkungan, kesehatan ibu, anak dan keluarga berencana; pelayanan gizi; pelayanan pencegahan dan pengendalian penyakit dan upaya kesehatan masyarakat pengembangan disesuaikan dengan prioritas masalah kesehatan di wilayah kerjanya dan potensi sumber daya yang tersedia di Puskesmas. Melalui adanya puskesmas, setidaknya dapat menjawab kebutuhan pelayanan kesehatan yang memadai yakni pelayanan kesehatan yang mudah dijangkau. Puskesmas berfungsi sebagai pusat penggerak pembangunan berwawasan kesehatan, Puskesmas pemberdayaan keluarga dan masyarakat pusat pelayanan kesehatan strata pertama. Secara umum, pelayanan kesehatan yang diselenggarakan oleh puskesmas meliputi pelayanan kuratif (pengobatan), preventif (pencegahan), promotif (peningkatan kesehatan) dan rehabilitasi (pemulihan kesehatan). Untuk mencapai derajat kesehat.

Untuk mencapai derajat kesehatan masyarakat yang setinggi-tingginya melalui upaya kesehatan seperti yang dicanangkan dalam Peraturan Menteri Kesehatan Republik Indonesia Nomor 43 Tahun 2019 tentang Pusat Kesehatan Masyarakat (Puskesmas) perlu adanya pelayanan kesehatan yang baik dan berkualitas oleh penyelenggara kesehatan, oleh sebab itu dituntut kinerja yang tinggi dari penyelenggara kesehatan itu sendiri.
Kepuasan pelanggan didasarkan pada terpenuhi atau terlampauinya harapan pelanggan. Loyalitas pelanggan dan profitabilitas perusahaan yang maksimal dalam jangka panjang diperoleh melalui kepuasan pelanggan. Puskesmas dalam upayanya meningkatkan pelayanan dan meningkatkan kepuasan pasien perlu mengadakan sistem pengukuran kepuasan pelanggan untuk dapat mengetahui kebutuhan dan harapan pasien mengingat bahwa harapan merupakan standar pembanding untuk menilai kualitas pelayanan di fasilitas kesehatan. Hasil pengukuran kepuasan pelanggan yang objektif dan akurat dapat membantu puskesmas dalam merumuskan bentuk pelayanan yang lebih baik. Kepuasan pasien sebagai fokus untuk meningkatkan kualitas pelayanan kesehatan dalam rangka pencapaian tujuan kesehatan masyarakat.

Pengaturan sistem layanan kesehatan atau prosedur puskesmas hendaknya tidak berbelit-belit, dapat dipahami oleh pasien, dan berfokus pada memberikan kemudahan bagi pasien dalam mengakses pelayanan dimulai dari penerimaan pasien. Irawan (2008) memaparkan bahwa pelanggan akan semakin puas apabila cara mendapatkan produk atau layanan relatif mudah dan efisien. Didalam Permenpan No. 14 tahun 2017 Tentang Pedoman Punyusunan Survei Kepuasan Masyarakat Unit Penyelenggara Pelayanan.

\section{METODE PENELITIAN}

Desain penelitian ini menggunakan studi deskriptif. Penelitian deskriptif adalah penelitian diarahkan untuk mendeskripsikan atau menguraikan suatu keadaan didalam suatu komunitas (Notoatmodjo, 2014). Penelitian ini hanya mendeskripsikan atau menggambarkan Tingkat Pengetahuan Akseptor KB Tentang Pil Kombinasi di Desa Mainan Kecamatan Sembawa Kabupaten Banyuasin.

Populasi dalam penelitian ini adalah Akseptor KB Pil Kombinasi yang bertempat tinggal di Desa Mainan Kecamatan Sembawa 
Jurnal Kebidanan : Jurnal Medical Science Ilmu Kesehatan Akademi Kebidanan Budi Mulia Palembang Volume.11 No.1, Juni 2021

Available online http://journal.budimulia.ac.id/

Kabupaten Banyuasin sebanyak 210 orang. Sampel dalam penelitian ini berdasarkan perhitungan jumlah sampel menjadi 44 orang. Penelitian ini dilakukan pada bulan Februari - Maret 2021 di Desa Mainan Kecamatan Sembawa Kabupaten Banyuasin.

Dalam penelitian ini instrument yang diguanakan adalah kuesioner yang berisikan karaketeristik responden yang meliputi umur, pekerjaan, paritas, alat kontrasepsi yang sedang digunakan. Kuesioner yang digunakan dalam penelitian ini adalah kuesioner tertutup, yaitu sudah disediakan jawabannya sehingga responden tinggal memilih (Swarjana,2015). Analisa data dalam penelitian ini menggunakan angka univariate yang dilakukan terhadap tidap variabel dari hasil penelitian.

\section{HASIL PENELITIAN}

\section{A. Karakteristik Faktor Perpektif} Kemudahan Akses Lokasi

\section{Kemudahan Dalam Mencapai Lokasi Puskesmas}

\section{Tabel 1 DistribusiFrekuensi Kemudahan Mencapai Lokasi Puskesmas}

\begin{tabular}{llcl}
\hline \multirow{2}{*}{ No } & \multirow{2}{*}{$\begin{array}{c}\text { rawaban } \\
\text { responden }\end{array}$} & \multicolumn{2}{c}{ Persentase Jawaban } \\
\hline \multirow{2}{*}{1.} & Ya & 79 & $\%$ \\
\hline 2. & Tidak & 1 & $1,2 \%$ \\
\hline & Jumlah & 80 & $100 \%$ \\
\hline
\end{tabular}

Berdasarkan tabel diatas dari 80 responden yang diteliti, didapatkan hasil 79 $(98,8)$ responden menjawab ya serta 1 $(1,2 \%)$ responden menjawab tidak. Dengan demikian dapat disimpulkasn bahwah mayoritas responden menyatakan kemudahan dalam mencapai lokasi puskesmas

\section{Aksebilitas Transportasi Umum}

Tabel 2 Distribusi Frekuensi Ketersediaan Akses Transportasi Umum

\begin{tabular}{|c|c|c|c|}
\hline \multirow{2}{*}{ No } & \multirow{2}{*}{$\begin{array}{l}\text { Jawaban } \\
\text { responden }\end{array}$} & \multicolumn{2}{|c|}{ Persentase Jawaban } \\
\hline & & $\mathbf{N}$ & $\%$ \\
\hline 1. & Ya & 65 & $81,2 \%$ \\
\hline 2. & Tidak & 15 & $18,8 \%$ \\
\hline & Jumlah & 80 & 100 \\
\hline
\end{tabular}

Berdasarkan tabel diatas dari 80 responden yang diteliti, didapatkan hasil 65 $(81,2)$ responden menjawab ya serta 15 $(18,8 \%)$ responden menjawab tidak. Dengan demikian dapat disimpulkasn bahwah mayoritas responden menyatakan ketersediaan akses transportasi umum ke lokasi puskesmas

\section{Kemudahan Dalam Ketersediaan Tempat Parkir}

Tabel. 3 Distribusi Frekuensi Kemudahan Dalam Ketersediaan Parkir

\begin{tabular}{clccc}
\hline \multirow{2}{*}{ No } & \multirow{2}{*}{ Jawaban } & \multicolumn{2}{c}{ Persentase Jawaban } \\
\cline { 3 - 5 } & responden & $\mathbf{N}$ & $\mathbf{\%}$ & \\
\hline 1. & Ya & 69 & $86,2 \%$ & \\
\hline 2. & Tidak & 11 & $13,8 \%$ & \\
\hline & Jumlah & 80 & & 10 \\
\hline
\end{tabular}

Berdasarkan tabel diatas dari 80 responden yang diteliti, didapatkan hasil 69 $(82,2)$ responden menjawab ya serta 11 $(13,8 \%)$ responden menjawab tidak. Dengan demikian dapat disimpulkasn bahwah mayoritas responden menyatakan ketersediaan tempat parkir di lokasi puskesmas.

\section{B. Kepuasan Pasien}

Tabel. 4 Distribusi Frekuensi Kepuasan Pasien

\begin{tabular}{ccccc}
\hline \multirow{2}{*}{ No } & \multirow{2}{*}{$\begin{array}{c}\text { Jawaban } \\
\text { responden }\end{array}$} & \multicolumn{2}{c}{ Persentase Jawaban } \\
\cline { 3 - 5 } 1. & Ya & 77 & $96,2 \%$ \\
\hline 2. & Tidak & 3 & $3,8 \%$ & \\
\hline & Jumlah & 80 & $100 \%$ & \\
\hline & Berdasarkan & tabel diatas dari & 80
\end{tabular}

responden yang diteliti, didapatkan hasil 77 $(96,2)$ responden menjawab ya serta $3(3,8 \%)$ responden menjawab tidak. Dengan demikian dapat disimpulkasn bahwah mayoritas 
Jurnal Kebidanan : Jurnal Medical Science Ilmu Kesehatan Akademi Kebidanan Budi Mulia Palembang Volume.11 No.1, Juni 2021

Available online http://journal.budimulia.ac.id/

responden menyatakan puas terhadap

pelayanan puskesmas

\section{Hubungan Perspektif Kemudahan Akses Lokasi Puskesmas dan Kepuasan pasien}

\section{Kemudahan Dalam Mencapai Lokasi Puskesmas}

Berdasarkan faktor kemudahan akses lokasi puskesmas dengan kepuasan pasien didapatkan data yang disajikan dalam tabel dibawah ini :

Tabel. 5 Hubungan Kemudahan Mencapai kemudahan dalam mencapai loakasi puskesmas dengan Kepuasan Pasien

\begin{tabular}{|c|c|c|c|c|c|c|c|c|}
\hline \multirow{3}{*}{ No } & \multirow{3}{*}{$\begin{array}{c}\text { Kemudaahan } \\
\text { Mencapai Lokasi }\end{array}$} & \multicolumn{4}{|c|}{ Kepuasan Pasien } & \multirow{2}{*}{\multicolumn{2}{|c|}{ Total }} & \multirow{3}{*}{$\begin{array}{c}\rho \\
\text { value }\end{array}$} \\
\hline & & \multicolumn{2}{|c|}{$\mathbf{Y a}$} & \multicolumn{2}{|c|}{ Tidak } & & & \\
\hline & & $\mathbf{n}$ & $\%$ & $\mathbf{n}$ & $\%$ & $\mathbf{n}$ & $\%$ & \\
\hline 1. & $\mathrm{Ya}$ & 77 & 97,5 & 2 & 2,5 & 79 & 100 & \multirow{3}{*}{0,038} \\
\hline 2. & Tidak & 0 & 0 & 1 & 100 & 1 & 100 & \\
\hline & Jumlah & 77 & 96,2 & 3 & 3,8 & 80 & 100 & \\
\hline
\end{tabular}

Berdasarkan tabel diatas, hasil uji ChiSquare didapatkan $p 0,038 \leq 0,05$, ini berarti $\mathrm{H}_{0}$ diterima bahwa ada hubungan antara
Kemudahan Mencapai kemudahan dalam mencapai lokasi puskesmas dengan Kepuasan Pasien.

\section{Aksebilitas Transportasi Umum}

Berdasarkan faktor aksebilitas transportasi umum dengan kepuasan pasien didapatkan data yang disajikan dalam tabel dibawah ini :

Tabel 6 Hubungan aksebilitas Transportasi Umum dengan Kepuasan Pasien

\begin{tabular}{|c|c|c|c|c|c|c|c|c|}
\hline \multirow{3}{*}{ No } & \multirow{3}{*}{ Kemudaahan Mencapai Lokasi } & \multicolumn{4}{|c|}{ Kepuasan Pasien } & \multirow{2}{*}{\multicolumn{2}{|c|}{ Total }} & \multirow{3}{*}{$\begin{array}{c}\rho \\
\text { value }\end{array}$} \\
\hline & & \multicolumn{2}{|c|}{$\mathrm{Ya}$} & \multicolumn{2}{|c|}{ Tidak } & & & \\
\hline & & $\mathrm{n}$ & $\%$ & $\mathrm{n}$ & $\%$ & $\mathrm{n}$ & $\%$ & \\
\hline 1. & $\mathrm{Ya}$ & 65 & 100 & 0 & 0 & 65 & 100 & \multirow{3}{*}{0,006} \\
\hline 2. & Tidak & 12 & 80 & 3 & 20 & 15 & 100 & \\
\hline & Jumlah & 77 & 96,2 & 3 & 3,8 & 80 & 100 & \\
\hline
\end{tabular}

Berdasarkan tabel diatas, hasil uji ChiSquare didapatkan $p 0,006 \leq 0,05$, ini berarti $\mathrm{H}_{0}$ diterima bahwa ada hubungan antara aksebilitas transportasi umum dengan Kepuasan Pasien. 


\section{Hubungan Ketersediaan Lahan Parkir yang Memadai dengan Kepuasan Pasien}

Berdasarkan faktor kemudahan akses lokasi puskesmas dengan kepuasan pasien didapatkan data yang disajikan dalam tabel dibawah ini :

Tabel.7 Hubungan Ketersediaan Lahan Parkir yang Memadai dengan Kepuasan Pasien

\begin{tabular}{|c|c|c|c|c|c|c|c|c|}
\hline \multirow{3}{*}{ No } & \multirow{3}{*}{$\begin{array}{c}\text { Kemudaahan } \\
\text { Mencapai Lokasi }\end{array}$} & \multicolumn{4}{|c|}{ Kepuasan Pasien } & \multirow{2}{*}{\multicolumn{2}{|c|}{ Total }} & \multirow{3}{*}{$\begin{array}{c}\rho \\
\text { value }\end{array}$} \\
\hline & & \multicolumn{2}{|c|}{ Ya } & \multicolumn{2}{|c|}{ Tidak } & & & \\
\hline & & $\mathbf{n}$ & $\%$ & $\mathbf{n}$ & $\%$ & $\mathbf{n}$ & $\%$ & \\
\hline 1. & $\mathrm{Ya}$ & 69 & 100 & 0 & 0 & 69 & 100 & \multirow{3}{*}{0,002} \\
\hline 2. & Tidak & 8 & 72,7 & 3 & 27,3 & 11 & 100 & \\
\hline & Jumlah & 77 & 96,2 & 3 & 3,8 & 80 & 100 & \\
\hline
\end{tabular}

Berdasarkan tabel diatas, hasil uji ChiSquare didapatkan $p 0,02 \leq 0,005$, ini berarti $\mathrm{H}_{0}$ diterima bahwa ada hubungan antara

\section{PEMBAHASAN}

\section{Hubungan Kemudahan Mencapai kemudahan dalam mencapai loakasi puskesmas dengan Kepuasan Pasien}

Berdasarkan hasil penelitian, hasil uji ChiSquare didapatkan $p 0,038 \leq 0,05$, ini berarti $\mathrm{H}_{0}$ diterima bahwa ada hubungan antara Kemudahan Mencapai kemudahan dalam mencapai lokasi puskesmas dengan Kepuasan Pasien. Kemudahan dalam mencapai lokasi tempat pelayanan memberikan pengaruh bagi pasien, terlebih lagi pasien dalam kondisi sakit. Pelayanan diartikan sebagai suatu proses pemenuhan kebutuhan melalui aktivitas orang lain secara langsung dengan bantuan manusia atau mesin secara fisik, dan bertujuan untuk menyediakan kepuasan pelanggan (Winarsih, 2013). Salah satu faktornya antara lain yang dikemukakan oleh Irawan, 2008 bahwa Biaya dan kemudahan adalah suatu pengorbanan yang dikeluarkan oleh pelanggan untuk mendapatkan produk atau pelayanan yang relative mudah, nyaman dan efesien. Adapun indikator dari variabel ini yaitu Lokasi mudah dijangkau dan Efesiensi biaya dan mudah
Ketersediaan Lahan Parkir yang Memadai dengan Kepuasan Pasien.

untuk memanfaatkan produk. Penelitian ini sesuai dengan Perrmenkes No. 43 tahun 2019, bahwa syarat- syarat pendirian puskesmas sehingga masyarakat mudah mengakses lokasi anatara lain faktor geografis yaitu puskesmas tidak didirikan di lokasi berbahaya, antara lain: tidak di tepi lereng, tidak dekat kaki gunung yang rawan terhadap tanah longsor, tidak dekat anak sungai, sungai atau badan air yang dapat mengikis pondasi dan tidak di daerah rawan banjir.

\section{Hubungan aksebilitas Transportasi Umum dengan Kepuasan Pasien}

Berdasarkan hasil penelitian, hasil uji ChiSquare didapatkan $p 0,006 \leq 0,05$, ini berarti $\mathrm{H}_{0}$ diterima bahwa ada hubungan antara aksebilitas transportasi umum dengan Kepuasan Pasien. Hasil penelitian ini sesuai dengan pendapat dari Irawan ,2008 bahwa biaya dan kemudahan didefinisikan dengan pelanggan akan semakin puas apabila relative mudah, nyaman dan efisien dalam mendapatkan produk atau pelayanan. Biaya yang dikeluarkan oleh pelanggan. merupakan pengorbanan dari pelanggan untuk 
menggunakan produk dari perusahaan. Biaya ini terdiri dari biaya berpikir, biaya transportasi dll. Sedangkan kemudahan adalah segala sesuatu yang didapatkan yang berupa kemudahan administrasi, pemesanan dan pelayanan dll. Biaya dan kemudahan diatas akan dapat berpengaruh terhadap kepuasan pelanggan, semakin terjangkau biaya yang dikeluarkan maka akan semakin mudah pelanggan mendapatkan produk maka pelanggan semakin puas. Hasil penelitian ini sesuai dengan penelitian yang dilakukan oleh Suhaji dan Sunandar, 2010 serta Yeti Desmiati, 2010 yang menyatakan bahwa biaya dan kemudahan berpengaruh positif terhadap kepuasan pelanggan.

\section{Hubungan Ketersediaan Lahan Parkir yang Memadai dengan Kepuasan Pasien}

Berdasarkan tabel diatas, hasil uji Chi-Square didapatkan $p 0,02 \leq 0,005$, ini berarti $\mathrm{H}_{0}$ diterima bahwa ada hubungan antara Ketersediaan Lahan Parkir yang Memadai dengan Kepuasan Pasien. Dari tinjauan pustaka Kurz and Clow (dalam Laksana,2008) Dengan ketatnya persaingan, masing-masing penyedia jasa dituntut untuk memberikan kualitas pelayanan yang prima kepada pelanggan agar kepuasannya terpenuhi. Dengan terpenuhinya kepuasan pelanggan maka pelanggan tersebut diharapkan tetap setia. Pelanggan yang puas adalah pelanggan yang akan berbagi kepuasan dengan produsen atau penyedia jasa. Bahkan, pelanggan yang puas, akan berbagi rasa dan pengalaman dengan pelanggan lain. Ini akan menjadi referensi bagi perusahaan yang bersangkutan. Oleh karena itu, baik pelanggan maupun produsen, akan sama-sama diuntungkan apabila kepuasan terjadi. pengaruh kualitas pelayanan terhadap kepuasan adalah jika pelayanan yang diberikan kepada pelanggan sesuai dengan yang diharapkan, maka akan memberikan kepuasan. Faktor ketersediaan lahan parkir yang memadai merupakan salah satu kebutuhan pasien dalam menerima pelayanan puskesmas, seperti yang tertuang dalam Perrmenkes No. 43 tahun 2019, telah dijelaskan syarat- syarat pendirian puskesmas sehingga masyarakat mudah mengakses lokasi termasuk didalammnya ditekankan untuk kategori lahan parkir Kapasitas parkir harus memadai, menyesuaikan dengan kondisi lokasi, sosial dan ekonomi daerah setempat.

\section{KESIMPULAN}

Terdapat hubungan yang bermakna antara kemudahan dalam mencapai lokasi (geografis) dengan kepuasan pasien di UPTD Puskesmas Sekar Jaya tahun 2020. Terdapat hubungan yang bermakna antara Aksebilitas transportasi umum dengan kepuasan pasien di UPTD Puskesmas Sekar Jaya tahun 2020. Terdapat hubungan yang bermakna antara ketersediaan lahan parkir dengan kepuasan pasien di UPTD Puskesmas Sekar Jaya tahun 2020 .

\section{DAFTAR PUSTAKA}

Usmara, 2003. Strategi Baru Manajemen Pemasaran, Amara Books. Yogyakarta.

Philip Kotler,1997. Marketing Management: Analysis, Planning, Implementation and Control, (New Jersey: Prentice-Hall Inc,), Ninth edition

H.A.S. Moenir, 2002. Manajemen Pelayanan Umum di Indonesia, Bumi Aksara, Jakarta.

Irawan, Handi, 2003. Membedah strategi Kepuasan pelanggan. Cetakan pertama: PT. Gramedia. Jakarta

Permenkes No. 43 tahun 2019 tentang Pusat kesehatan masyarakat.

Permenpan No. 14 tahun 2017 tentang pedoman Penyusunan Survei Kepuasan masyarakat Untuk Penyelenggara Publik.

Prabowo. 2002. Majamenen Jasa. Salemba Empat . Jakarta. 
Jurnal Kebidanan : Jurnal Medical Science Ilmu Kesehatan Akademi Kebidanan Budi Mulia Palembang Volume.11 No.1, Juni 2021

Available online http://journal.budimulia.ac.id/

Ratminto dan Atik Septi Winarsih, 2013.Manajemen Pelayanan, Pustaka Pelajar, Yogyakarta.

Sinambela, Lijan Poltak. 2015. Manajemen Sumber Daya Manusia. PT.Bumi Aksara, Jakarta.

Suryani, Tutik , 2010. Jurnal Manajemen Publik dan Bisnis. Volume 1 No.1 edisi Februari 2010.
Yeti, Desmiati. 2010. Pengaruh Kualitas Pelayanan dan Harga terhadap kepuasan pelanggan Esia di Wilayah Jakarta Selatan. Jurnal Manajemen Publik dan Bisnis. Volume 1 No.1 edisi Februari 2010. 
